\title{
Music and Politics: A Class for Non-Majors
}

\section{PATRICIA HALL}

My introduction to music and politics originated from a pedagogical need: I was scheduled to teach a class at the UC Center in Washington, D.C., and my colleague at the time, Michael Beckerman, suggested, "How about Music and Politics?" I liked the idea, and since I envisioned some sort of historical survey, I consulted with other colleagues (Robert Freeman and Alejandro Planchart) to learn the most burning issues in music and politics in their areas of historical expertise. We quickly arrived at the following topics:

\section{Philip the Fair and Le Roman de Fauvel}

2. Music as Propaganda: The Court Composer in the Renaissance

3. The Politics of Religion: Music in the Reformation

4. The French Revolution as Mirrored in Classical Austrian Opera

5. Music in the New World: The Song of Protest

6. Wagner as Nazi Ideal

7. Berg's Wozzeck and the National Conscience

8. The 60's: "Fixin' to Die in Vietnam”

9. Music in the 90's: Rap and Censorship

Since the quarter system at UCSB allowed only three lectures for each topic, I planned to present each topic by featuring a particular musical work and closely examining the governmental system that influenced it. In addition to varying the historical periods, I wanted to feature different countries, different political systems, varying genres, and different tactics by the composers to deal with each political situation. In this way, students (mostly juniors and seniors) would be exposed to a historical overview, as well as variety in the type of music they listened to. (See Appendix I for syllabus for Music and Politics, arranged for a six-week summer term.) The course would begin with a genre that would be unfamiliar to most (the medieval motet) and end with something extremely familiar (rap). In addition to listening to music, I wanted to make the class extremely visual in nature, including a "Focus on Art" for each era that would make the historical style immediately recognizable by emphasizing the same properties as the music. For some periods this was quite challenging: What do you choose as a "Focus on Art" for slave music, since the art produced by slaves was often even more fragile and underappreciated than their music? After consultation with other scholars I finally arrived at the idea of slave quilts. Although most of the priceless examples that survive today are housed in museums, they were originally produced from materials at hand-often scraps of fabric from the main house. They were purportedly used as signals in the Underground Railroad, they retained stylistic features from the slaves' country of origin, and they performed a utilitarian function. All of these features can be applied to slave songs, as well. 


\section{Music and Politics Winter 2007}

Some of the "Focus on Art" assignments required active participation, for instance, the "Illuminating Kit" which could be checked out from the Arts Library. A surprising number of students choose to illuminate as an extra credit project. The supplied model color images from Le Roman de Fauvel allow a great deal of choice. While some students paint architectural details, others prefer to paint humans and animals:
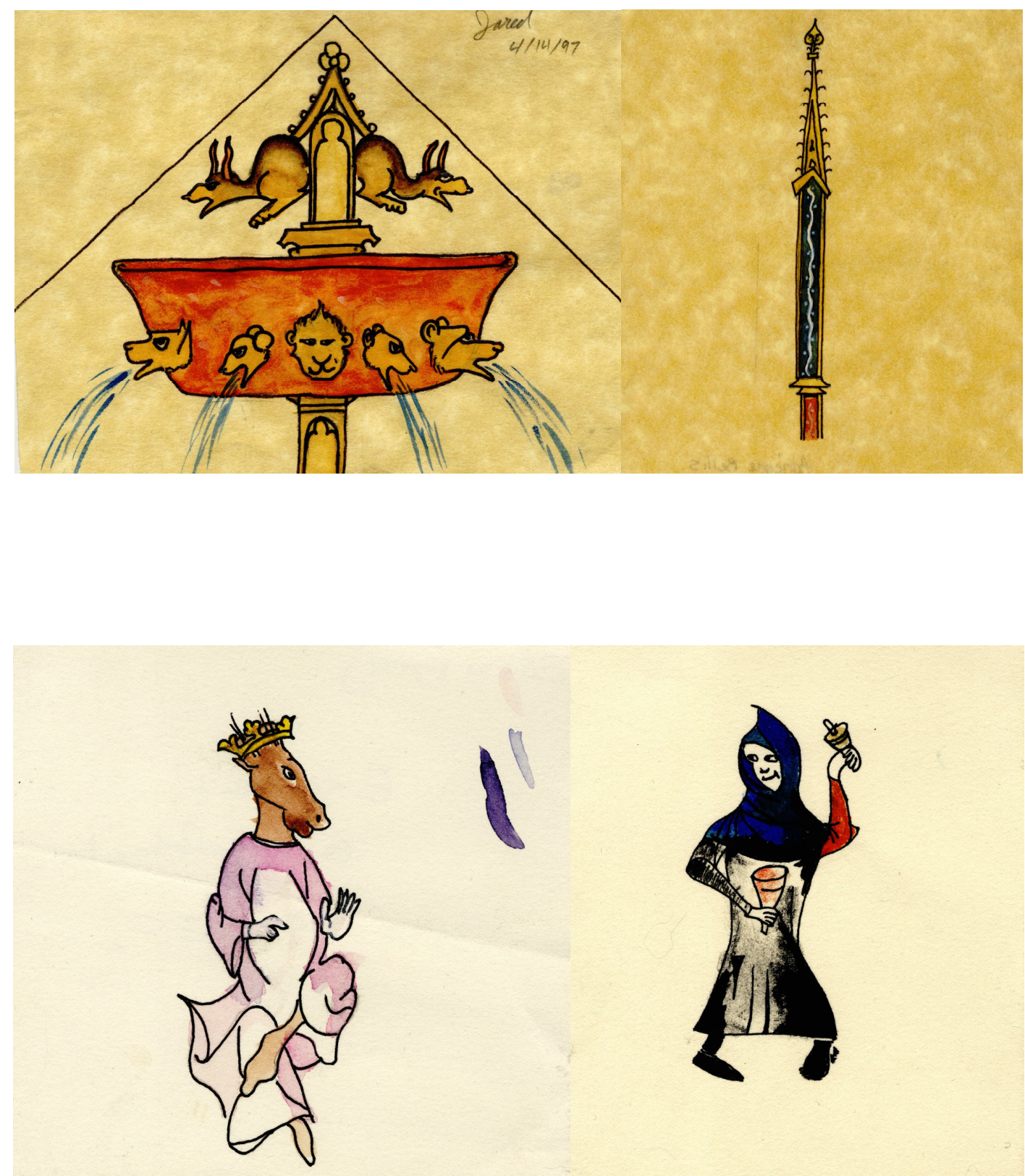
Film was another visual medium that brought historical eras to life. We watched recreations of court music in Elizabeth, Baroque opera in Farinelli, and a newsreel of Furtwängler conducting the overture to Die Meistersinger in an armaments factory. These and other films gave us a better sense of how this music functioned in its social context.

Finally, as a General Education Class fulfilling the Arts Requirement, the course was Writing Intensive, meaning that students had to write 1800 words in some format. Rather than a single paper, I asked students to write 300-word "journals" on six of the nine topics, which they would submit together in a folder. That allowed me to make ongoing comments on their writing, and to see its progression over the course of a quarter. Again, because of the intensive nature of the quarter system I made frequent short presentations of writing principles from Joseph Williams, Style: Toward Clarity and Grace, dependent upon the problems I assessed from their writing. I often presented examples of model prose on music and politics, for instance Gunter Grass's unforgettable description of Heinrich Schütz in The Meeting at Telgte:

He did not come alone. The Königsberg cathedral organist, who had made a name for himself well beyond the borders of Prussia as a composer and a publisher and was known in particular for the successive volumes of his "arias," was accompanied by his cousin Heinrich Schütz, Kapellmeister at the court of Saxony, who was on his way to Hamburg and then to Glückstadt, where he hoped to find a long-coveted invitation to the Danish court. There was nothing more to keep him in Saxony. In his early sixties like Weckherlin, but more robust than the Swabian, who had worn himself out in government service, Schütz was a man of austere authority and stern grandeur, whom no one (except Albert, and he only in part) could fathom. His presence-far from overbearing, he seemed troubled by fear of being in the way-raised the tone of the poets' gathering but at the same time reduced the measure of its importance. A man whom no group could endure had come to their meeting. ${ }^{1}$

Sometimes these readings were articles from the New York Times, for instance, the report on the concert of the Vienna Philharmonic of Beethoven's Ninth that took place in the quarry at the former Mauthausen Concentration Camp, and the ensuing controversy about not only the performers, but the repertoire in respect to this venue. ${ }^{2}$

I also wanted students to fully engage with each topic, rather than simply learn terms and dates. I chose questions for their journals that had no right or wrong answer, rather they necessitated that the student absorb the readings and think about how the topic applied to them. In the Wagner segment, I asked students, "If Wagner were alive during the Third Reich, would he willingly have served as its musical leader?" For the Wozzeck topic, students practiced role-play in their writing: "You are a psychiatrist who has been asked to evaluate a new Patient, Johann Christian Wozzeck. What is your diagnosis, and how might you help him deal with his daily life? (No drugs.)" This query has resulted in endless creative evaluations, suggesting yoga, family therapy, divorce from Marie, a warm puppy, as well as pleas for medication.

\footnotetext{
${ }^{1}$ Gunter Grass, The Meeting at Telgte, trans. Ralph Manheim (San Diego, 1981), p. 41.

${ }^{2}$ Roger Cohen, "Music at Site of Nazi Camp Ignites Protest," New York Times, 6 May 2000, and James Oestreich, "Arts Abroad: Dissonance in the Shadow of Death; Beethoven and Kaddish Echo Through a Nazi Camp Site," New York Times, 9 May 2000.
} 
$4 \quad$ Music and Politics Winter 2007

One particularly inventive evaluation appears below:

Commentary \#5

\section{University of Strasbourg Medical Centre}

Initial Inpatient Psychiatric Evaluation

$$
\text { Doctor: JASON SCHEIL }
$$

Patient Name:

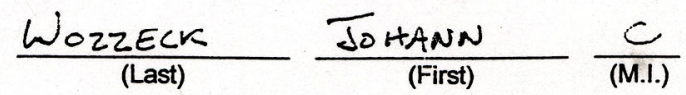

Social Status:
(Please Check One) King _ Clergy _ Noble _ Peasant

Reason for Commital: public ranting; deviant behavior; nervous

tension (possible Anxiety Aisorder); suicidal tendencies

Patient's Physical Condition: drenched in water; blood stains

about hands \& clothes; beaten physically

Known Ailments: Dysentery _ Cholera _ Plague(Black) $N / A$

$$
\text { Madness } \square \text { Leprosy _ Curse ? }
$$

Initial Contact Description: patient experiencing extreme hallacinations; severe in feriority complex; inability to cope with reality; fragmented speech pattern; complains frequently of a "red mist" Treatment Recommendation: partial seclusion; mandatory attendance to "Caste System: Know Your Place" seminar; Group therapy; prolonged castigation by warious noblemen

Medical Treatment (if any): See below

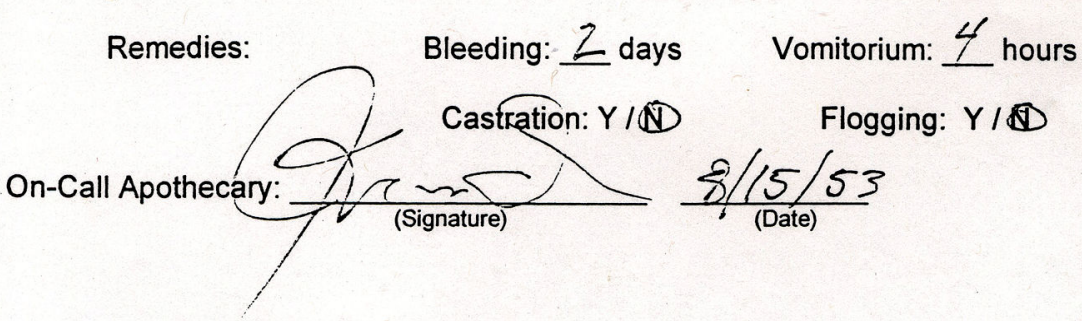


In lecture I usually introduce each topic with an overview of the setting and governmental system. In the case of Philip the Fair (1285-1314), the setting is Paris in the early $14^{\text {th }}$ century, which then had a population of around 200,000 (and a life expectancy of approximately 30!). Highlights of his reign include: war with England and Flanders; the assault on Pope Boniface VIII (1303); the removal of the papacy to Avignon (1309-77); the suppression of the Templars (1307-14); the expulsion of the Jews in 1306; the marriage contract of his four-year-old daughter Isabelle with the future Edward II of England; levies of fines against the populace; and uniform coinage. (Many of these events can be supplemented with color slides.) This overview leads easily to Lecture 2, a discussion of the poem by Gervais de Bus, the medieval motets featured in class listening, performance practice of medieval music, and finally, Lecture 3: the medieval aesthetic in art (illustrated with medieval manuscripts); materials used to create medieval manuscripts (which I pass around in class); and finally medieval warfare as portrayed in Braveheart.

Even back in 1997, when I first began to plan this course, UCSB was adventurous on the digital front. Instructional Development at UCSB graciously offered to audio stream the listening examples for each unit so that students could access the listening from their laptops rather than use up endless hours of staff library time in listening booths. When a new class web platform (powered by Moodle) came on the scene, I put the entire class online. Not only did Moodle allow students to submit commentaries and receive comments online, but it also input their grades in a grade book. It had other intriguing features that seemed made to order for the class: online discussion streams, announcements of upcoming events (for instance, guest speakers and exams), the ability to post folders with relevant art and political images, and most importantly, links to other web pages. One of our favorites I found by chance while searching for links on illuminated manuscripts: British Museum Turn the Page Books. This site posts the star manuscripts of the British Museum, allowing you to magnify images, manually turn the pages, and hear commentary about each leaf. In Mozart's Thematic Catalogue, one can even hear a fortepiano rendition of each theme. Since many of my students do not read music, this is an opportunity for them to hear the music, rather than just look at a manuscript. Like many of my assignments, the issue of choice is fundamental. While many students are intrigued by the depictions of farm life in the Lutrell Psalter, engineering students are attracted to Da Vinci's sketches of war machines.

The format of the class allows me to experiment as well. (Music and politics is an ever-evolving topic, after all.) During the last two summer sessions, an attorney and graduate student in music theory, Leo Fishman, has given a very popular lecture called "Obscenity and Insanity," defining the legal definitions of those terms. (A number of my students are invariably pre-Law.) When Michael Moore's Fahrenheit 9/11 premiered in theaters, we discussed the audience reaction and whether, as many film scholars posited, the film was documentary or propaganda. Last summer, I invented a feature called "Ask the Author." One student and my Teaching Assistant each submitted a question to Shirli Gilbert, author of one of our readings on music in the Holocaust. ${ }^{3}$ Professor Gilbert responses to both questions were read in class the next week.

\footnotetext{
${ }^{3}$ Shirli Gilbert, Music in the Holocaust: Confronting Life in the Nazi Ghettos and Camps (Oxford, 2005).
} 


\section{Music and Politics Winter 2007}

What began as a suggestion from a colleague, Music and Politics has been an extremely gratifying teaching experience that has allowed me to continually enlarge my knowledge of the subject matter. (I taught a new class, Music in Political and Propaganda Films at the UC Washington Center last fall.) Moreover, my students inform me of new films, web pages, and recordings in what has become a twoway learning process. I hope that this article will stimulate ideas for other classes. 


\section{Appendix I: Syllabus}

\section{MUSIC 119A/ MUSIC AND POLITICS}

\section{WEEKLY TOPICS AND ASSIGNMENTS}

WEEK 1A: Introduction: Why Music and Politics?

Some Elements of Music

Good Writing / Writing about Music

Introduction to the Microcomputer Lab and Class Web Page.

Examples of meter, syncopation, consonance, dissonance, dynamics, tempi.

\section{WEEK 1B: Philip the Fair and Le Roman de Fauvel}

'Reading: Barbara Tuchman, A Distant Mirror: The Calamitous 14th Century (New York: Ballantine Books, 1978), 24-48.

Focus on Art: Illuminated Manuscripts

*Commentary: What writing techniques does Barbara Tuchman use to engage her reader?

*Listening: Two selections from Le Roman de Fauvel: Garrit Gallus-In nova ferte; (Philippe de Vitry) and Je vois doleur-Fauvel nous a fait present. (anonomous)

Extra Credit: Illuminating a Medieval Manuscript. Use the "Illuminating Kit" to paint a detail from Le Roman de Fauvel. Brushes, parchment, paint and examples on reserve in the Arts Library.

WEEK 2A: Music as Propaganda: The Court Composer in the Renaissance

"Reading: A. Dunning, "Introduction to State Music" pp.3-8.

*Film: Excerpt from Queen Margot

Focus on Art: Political Engravings; Albrecht Dürer

*Commentary: Describe a scene from Queen Margot. Do you feel that film is a valid tool to teach history?

*Listening: Henry VIII, "Pastime with good company"; Josquin Desprez, "De profundis"; Clement Janequin, "La Guerre." 
WEEK 2B: The Politics of Religion: Music of the Reformation

*Reading: John M. Todd, Luther, A Life (London: Hamish Hamilton, 1982), 199227.

Guest Lecturer: Deborah Gentry, "The Thirty Years' War in 30 Minutes"

Focus on Art: Protestant Propaganda

${ }^{*}$ Commentary: The reading on Luther contains personal letters that were not meant to be circulated. Do these letters add or detract from the image of Luther as a great religious leader?

*Listening: Heinrich Schütz, "Ich bin die Auferstehung," "O lieber Herre Gott"; J.S. Bach, Kantate 80, "Ein feste Burg ist unser Gott," I and VIII.

Extra Credit: Experience the world of Baroque opera; attend a screening of Farinelli (1145 Music, time and date TBA).

\section{WEEK 3A: The French Revolution as Mirrored in Classical Austrian Opera}

*Reading: Somerset de Chair, ed., Napolean on Napolean, (London: Cassell, 1992), 196-215.

Films: Excerpts from The Marriage of Figaro and Fidelio.

Focus on Art: Personal Artifacts

*Commentary: In the past few weeks we have have seen several examples of musical gender blenders: castrati, counter-tenors and Hosenrollen. Describe ONE of these characters. Did you find his or her performance convincing?

"Listening: "Se vuol ballare, signor contino" from Mozart's The Marriage of Figaro; Beethoven, Leonore Ooerture \#3.

Extra Credit: You have been commissioned to create a new video game entitled Napolean! Write a flow chart showing the path of history, and history as it might have been. Consider adding appropriate theme music.

MIDTERM THURSDAY WEEK 3B: Includes musical identification (5) and multiple choice (30). Sample exam on reserve in the Arts Library. 
WEEK 4A: Music in the New World: The Song of Protest

*Reading: B.A. Botkin, ed., Lay my Burden Down: A Folk History of Slavery (New York: Dell, 1994), 94-103; 167-69.

Focus on Art: Slave Quilts

*Commentary: Describe the statue, Abraham Lincoln with Figure of Liberty

Unshackled. What was your reaction to this statue? (Slides on reserve.)

*Listening: "Follow the Drinkin Gourd," "No more auction block for me," "I'm in the bottom," "My Lawd's gitting us ready."

Extra Credit: Watch the video, Frederick Douglass: When the Lion wrote History (on reserve in the Arts Library).

\section{WEEK 4B: Wagner as Nazi Ideal}

${ }^{\star}$ Reading: Peter Adams, The Art of the Third Reich (New York: Harry N. Adams, Inc., 1992), 23-28. Charles Osborne, ed., Richard Wagner: Stories and Commentaries (London: Peter Owen, 1973), 23-39.

Film: Excerpts from Die Meistersinger and Siegfried

Focus on Art: "Degenerate Art"

*Commentary: If Wagner were alive during the Third Reich, would he willingly have served as its musical leader?

"Listening: Wagner, Overture to Tannhäuser; Wagner, "Die Frist ist um" from Der fliegende Holländer, "Tsvey Taybelech" (composer unknown).

Extra Credit: Video,For the Living: The Story of the United States Holocaust Memorial Museum (on reserve in the Arts Library) OR experiment with the Maus CD-ROM at IC for one hour and critique the CD-ROM.

WEEK 5A: Berg's Wozzeck and the National Conscience

*Reading: Douglas Jarman, Alban Berg, Wozzeck (Cambridge: Cambridge University Press, 1989), 1-6, 152-53.

*Film: Act I ofWozzeck

Focus on Art: Wassily Kandinsky 
*Commentary: You are a psychiatrist who has been asked to evaluate a new patient, Johann Christian Wozzeck. What is your diagnosis, and how might you help him deal with his daily life? (No drugs.)

${ }^{*}$ Listening: Wozzeck, Act I, scene 2

Extra Credit: Kandinsky Slide Search, TBD (on reserve in the Arts Library).

WEEK 5B: The '60's: "Fixin' to Die in Vietnam"

*Reading: Robert S. McNamara, In Retrospect (New York: Random House, 1995), 318-335.

Guest Lecture: Professor Richard Flacks, Department of Sociology

Film: Excerpt from Maya Lin, A Strong Clear Vision

Focus on Art: The Vietnam Memorial Wall

*Commentary: Describe one of the objects left at the Vietnam Wall. What does this object tell you about the person who left it, and the veteran it was left for? (Slides and book on reserve.)

"Listening: "We shall overcome," (Pete Seeger), "Waist Deep in the Big Muddy" (Pete Seeger), "Fixin' to Die Rag" (Country Joe McDonald), "I ain't marchin' anymore" (Phil Ochs), "The Star Spangled Banner" (J. Hendrix).

Extra credit: Create a short discography of five of your favorite anti-war songs. Find call numbers for these recordings in the Music Library.

WEEK 6A: Music in the 90's: The Politics of Censorship

*Reading: Selected Recent Articles from the New York Times and Tricia Rose Black Noise (Hanover: University Press of New England, 1994), 1-20.

Focus on Art: Graffiti

*Commentary: "Hate words" are no longer acceptable forms of expression. Why then, do some best-selling CD's use equally derogatory terms about women?

Listening (optional): Selections by 2 Live Crew, N.W.A.

Extra Credit: Write a socially conscious rap text of approximately 20 lines.

WEEK 6B: ADDITIONAL TOPICS, REVIEW FOR FINAL 